\title{
The curator in the art world and in the museum: History, theories and current issues
}

\author{
E. V. Rubantseva ${ }^{1}$, L. Hoffmann ${ }^{2}$ \\ ${ }^{1}$ St. Petersburg State University, \\ 7-9, Universitetskaya nab., St. Petersburg, 199034, Russian Federation \\ ${ }^{2}$ Sorbonne University, \\ 21, rue de l'École de Médecine, Paris, 75006, France
}

For citation: Rubantseva E. V., Hoffmann L. 2020. The curator in the art world and in the museum: History, theories and current issues. The Issues of Museology, 11 (2), 168-182.

https://doi.org/10.21638/11701/spbu27.2020.203

The article analyzes the current state of curatorship and curating from a historical, theoretical and practical perspective. The aim is to understand the origin and the nature of the justified critique facing the profession nowadays from art institutions, artists, as well as from curators themselves, while exploring the challenges faced. The key historical developments of the profession are retraced, which nonetheless always had, to a certain extent, to come to terms with the main stakeholders of the industry: the artist, exhibiting institutions and the public. The profession's interwoven position is further studied through a variety of positive and normative accounts from curators as well as from academia. These accounts make it possible to evaluate a profession whose complexity is reflected in its various practices, functions and officiating venues. Based on the historical and theoretical analysis, the authors explore the current position of the curator in the art field, as well as problems and criticism faced. Among them, significant attention in the article is paid to the ethical problems arising from the cooperation of curators with artists, institutions and the public, as well as to the alarming convergence of the functions of independent and museum curator and to the partially negative impact of working conditions on the quality of work of these professionals. The authors come to the conclusion that curatorship, because of its specific emergence in the world of art, faces new challenges that cannot be fully resolved because they are unavoidably placed between stakeholders sharing mostly antagonistic values.

Keywords: curatorship, exhibition, curator, independent curator, museum curator, types of curators, history of curatorship, museum, biennial, artist.

\section{Introduction}

Curatorship might be the most en vogue profession in the world of art today. Idolized by many, criticized to the same extent, its roles and functions remain a baffling challenge for those trying to define it today. In fact, the curator might even be the embodiment of the art industry itself to the extent that trying to make sense of this profession comes down to studying the entire industry of art, its history and its evolution until today. This paper tries to shed light on the current condition and problems facing the profession today as much in relations with other stakeholders as towards the organizations employing curators.

The ever evolving nature of curating can best be understood by analyzing the history of art through the interaction of the artist and the institution exhibiting his artwork. The

(C) St. Petersburg State University, 2020 
emergence of curating is the story of a profession lying in between the public and the artist; one could even say that this is its very nature. But this unique position in the art sphere puts the curator in a situation whose complexity transpires as much in academic research as well as among professionals themselves. This complexity leaves the profession with questionings ranging from everyday best practices to the core nature of its profession. A profession today, as yesterday, which has to make sense of the industry it operates in while bearing in mind the criteria of its inception, one of a "carekeeper".

In order to grasp the challenges and dilemmas curatorship faces nowadays we decide to go back to its young and dynamic history. While the function of curator as we know it is relatively recent, the term "curator" goes back to the Middle Ages. Needless to say, that the curator at that time does not resemble the curator of today. We thus try genealogically to reconstruct the key period that characterized the coming-of-age of curating.

The historical part of our paper lays the ground for the wide range of definitions of the profession as we find it today. This selection, undoubtedly, allows us to apprehend the multiple sides of curating which will help to better transition to the aspect of our paper covering the current problems challenging the profession that seem urgent to shed a light on today.

\section{A history of curating}

The long history of presenting art to the public undeniably helps us retracing the milestones curatorship had to go through in order to acquire the position it has today. By choosing a genealogical perspective on the evolution of curating we wish to better understand the complexity of issues facing curators today by linking them to significant historical events.

If we turn to the etymology of the word "curator" we then see its origin coming from the Latin word "curare" - to take care of something1. Literally the concept of "curator" first came into use in the middle of the $14^{\text {th }}$ century in the meaning of "attendant", "keeper" or "guardian". Exactly at that time the practice of collecting various objects became widespread and the first collections were formed in the shape of cabinets of curiosities, Kunstkameras, Wunderkammern. With time these collections turned into first museums, and the roles of curators, keepers and directors got closely intertwined, even though a curator was meant mostly as an attendant of museums' and other types of collections ${ }^{2}$. On the other hand, the activity of curator in a museum from the $18^{\text {th }}$ century onwards has evolved into including ever more functions, such as heritage conservation, the selection of new objects and artworks, scientific research and educational activities without forgetting organizing exhibitions ${ }^{3}$. Eventually, it is this very last aspect which turns out defining the profession of curator as we know it today.

Let us turn our attention to the history of art exhibitions. Until the $17^{\text {th }}$ century the exposition of living artists was almost non-existent, most artists would be commissioned by wealthy individuals rendering their artwork localized and not very mobile. This reality started to change in France during the end of the $17^{\text {th }}$ century with the opening of the Salon under the Académie royale de peinture et de sculpture which was the first official

\footnotetext{
${ }^{1}$ Obrist, 2016. P. 28.

${ }^{2}$ George, 2017. P. 10-12.

${ }^{3}$ Obrist, 2016. P. 29.
} 
institution exhibiting living artists and which would regularly renew their exposed artworks. The Salon would expose (at first) in an irregular fashion the academic laureates and allowed for a growing public to get acquainted with the recent novelties of the art milieu. The selection and exposition of the Salon artworks would in the middle of the $18^{\text {th }}$ century be allocated to a jury which would be responsible for the success of the exposition in relation to the Académie but also towards the public. The jury being the sole responsible for the art exposed, would be propelled at the center of debates and criticism from the public but especially from the artists not having their work selected. This is exactly what happened in the end of the $19^{\text {th }}$ century with the evolution of the art industry. The growing number of art merchants as well as an increased interest from the public made it possible for independent art movements to gain visibility by bypassing the jury of the Salon. The year 1874, for example, marked the occasion for the Impressionist movement to expose their own works outside of the influence of the Salon by uniting artists around common characteristics chosen only by themselves. The gatekeeping role played by the jury of the Salon as a "collective curator" 4 turned out to be a prelude to the organization of modern curatorship in biennales or elsewhere where a constant back and forth between the curator and the artist is needed.

Another essential step in the inception of curating took place in the beginning of the $20^{\text {th }}$ century, when the avant-garde appeared on the art scene. The various displays of avant-garde artists represented an important stage in the development of exhibition activities because art movements at that time were using exhibitions not only as a way to showcase their art but also as a tool of artistic expression. Famous for their critique of "bourgeois art institution", members of the avant-garde aspired to break the traditional design of the expositions ${ }^{5}$. But aside from the changes in the ways of representation, art itself changed dramatically too. New non-figurative and conceptual art needed new displays as well as the framing of the artists' ideas into shareable interpretations.

Other reasons to explain the rise of curatorship comes from the fact that museums at the same time were evolving as institutions. These changes were that new collections of modern art needed to be presented not in traditional museum environment because there weren't enough opportunities to emphasize one or another interpretation of meanings, important pieces, etc. ${ }^{6}$ Therefore, one of the first new museum institutions for modern art collections was founded in 1929 in New-York. Well-known today as MoMA, Museum of Modern Art in New York positioned itself from the very beginning as a qualitatively new museum space which keeps up with the times and as a place for art experiments and discussions.

The 1960s saw the appearance of ever more contemporary art institutions outside of the mainstream commercial galleries and traditional museums. These institutions took the form of Kunsthallen, contemporary art museums, biennials or even artists residences. These new art installations should be places of "discourse, debate, reverie, enlightenment, and inspiration" according to Nicholas Serota ${ }^{7}$, the director of the Tate Gallery of London for more than thirty years. But these new emerging institutions are prone to look up at the avant-garde of the early $20^{\text {th }}$ century while at the same time being critical of the idea

\footnotetext{
${ }^{4}$ Glicenstein, 2015. P. 31.

${ }^{5}$ O’Neill, 2015. P. 20-21.

${ }^{6}$ Safronov, 2019. P. $75-76$.

${ }^{7}$ Marincola (ed.), 2001. P. 84-85.
} 
of self-organized artists ${ }^{8}$. The ambiguous relation between artists and curators (or their historical equivalent) seems to have always been a tumultuous one, one that is rooted in conflict but also in temporary collaboration as much as in mutual admiration.

With art becoming increasingly conceptual, where meaning is the most important and not the aspect of the art piece, everything could potentially become an artwork and as a result the figure of the author might see its importance diminish. At the same time the production of meanings develops as an independently essential practice in the art sphere. These processes objectively led to the situation characterized by the transition of primary authorship from artist to curator. The artist, who used to be a demiurge (master, creator) until this moment, becomes almost an ordinary link in the creative process author - curator - gallery - museum - art market, etc. As a result, the connection between the artist and the public begins to acquire an indirect character and becomes many times more complicated ${ }^{9}$. Even though this common trend, of course, is not describing all the cases, there still are artists whose creative work is highly essential in itself.

The awaited appearance of a conscious curatorial practice came to age in the 1960s and 1970s, thanks to the assemblage of artistic events at that time - mainly from the exhibitions of the first curators in the full sense of the word. The most iconic of them, rightfully considered a milestone, dividing curatorship into "before" and "after" is Harald Szeemann's exhibition "When Relationships Become Form", shown in 1969 at the Bernese Kunsthalle. It is with this exhibition that the history of modern curatorship begins with. Szeemann brought together a wide range of international artists who turned to procedural and socially interactive forms of work. The exhibits on display were not so much selfsufficient pieces of art as the result of the actions of the artists deployed in time. Therefore, procedurality, unpredictability and performativity have become as much a part of works as of the exhibition itself. A thoughtful reading of the exhibition assumed that the viewer's attention should be directed not only to the objects on display, but also to the figure of the exhibition organizer who conceived this procedural event, built its drama and directed its course in time ${ }^{10}$.

At this stage of its development, curating achieved a new stepping stone. If before it was dealing with simply selecting works of art and its best representation to mediate the artists and the public, now the curator creates his own concept and accomplishes an independent artistic expression. At the same time, curatorship gradually breaks with the museum that gave birth to it and stands out as a profession, free from the restrictions of institutions. Indeed, after his famous exhibition which became scandalous Szeemann was forced to resign from the post of director of the Kunsthalle and became the first independent curator, founding the Agentur für Geistige Gastarbeit ("Agency for Spiritual Migrant Work") - an organization dealing with the creation of exhibitions.

These lines of development of the institution of curatorship continued to shape its history in the 1980s. A new phenomenon of this decade, which confirmed the final formation of curatorial activity, was the emergence of the first educational programs dedicated to curatorship. In 1987, in Grenoble, the "Le Magasin Center for the Arts" launched Europe's first curatorial curriculum program for graduates - l'Ecole du Magasin, which still exists today. In the same year, the Whitney Independent Research Program renamed

\footnotetext{
${ }^{8}$ Glicenstein, 2015. P. 39.

${ }^{9}$ Safronov, 2019. P.76.

${ }^{10}$ Miziano, 2014. P. 13-14.
} 
its Art History/Museology Study Group into the Curatorial and Critical Research. It was during this time that the curatorial practice became both an academic discipline and a profession in its own right ${ }^{11}$.

The real flourishing of curating began already in the 1990s, which is directly related to the widespread dissemination of the biennial format at that time, due to the general trends towards globalization. The institutional structure behind the Biennale has come to support the illusion of an all-encompassing curatorial inspiration or even genius, and in the absence of any alternative narratives or substantial opposition, the curator has become the entity most clearly responsible for the production and mediation of the biennial ${ }^{12}$. Ultimately, the figure of the curator became extremely popular and in demand, and their exhibitions began to be perceived as full-fledged, independent works of art. However, the curators faced criticism against them, primarily from the artists who participated in their projects. The artists accused the curators of realizing their own selfish goals and ideas, suppressing the works of art themselves, which they used only as "raw materials" for their own expositions.

At the beginning of the $21^{\text {st }}$ century curatorship as a kind of professional activity continues its active evolution. The current stage of its development is associated, first of all, with internal criticism of their peers, with attempts by curators to comprehend their own practice and their place in the modern art industry. It is expressed in the creation of specialized curatorial journals (Manifesta Journal of Contemporary Curatorship, published since 2003; The Exhibitionist, since 2010; Journal of Curatorial Studies, since 2012) and holding conferences, open tables, and other types of curatorial discussions ${ }^{13}$. Also, among the trends in the development of curatorial practice in recent years, one can attribute the increasing attention paid to the issues of curatorial ethics in relations with institutions, the public and the artists.

\section{Theoretical approaches to curating}

We previously saw the correlation between the evolution of the art industry and the occupation of curator. This constant intertwinement has been described on numerous levels so far. May it be in the direct relation with the artist himself, with the institution for which he works and through the values of his work; the curator is at the juncture of the challenges facing the art world.

These challenges in their current forms have morphed into the handling of criticism coming from inside and outside of the profession as well as the conceptual work of defining curatorship to give it its letter of nobility. It is this second aspect that we are going to focus on in this part in order to give the closest account of the literature studying curating.

The definitions concerning the profession of curator are numerous and can take a wide range of approaches. The selection we undertook was meant at being the most able to highlight the difficulties contemporary curators likely have to bear.

\footnotetext{
11 O'Neill, 2015. P. 7-8.

12 Ibid. P. 101.

13 Ibid. P. 80.
} 
The most general and popular division to define curators which is under consideration of many researchers nowadays is the separation between museum (institutional) and independent curators ${ }^{141516}$.

A museum or institutional curator (or хранитель, conservateur, conservatore, Konservator in other languages) is a professional working as part of various institutions, usually large organizations with extensive collections ${ }^{17}$. Within the framework of museology, a "curator" is also defined as the head of a museum exhibition project of any scope in a museum of any profile ${ }^{18}$.

A museum curator is usually assigned in his work by his professional specialization, most often connected with a certain artistic collection he is in charge of. Changing specialization is possible, but hard for this specialist ${ }^{19}$. A museum curator is primarily engaged in the preservation of artworks, in their research and collection development as well as organizing exhibitions, which is only one of his duties among the wide range of others. $\mathrm{He}$ cares both about improving the permanent exhibitions and organizing temporary ones, which involves a high share of research activities, serious and at the same time original presentation of artistic material. The result of his activity is the building of a significant museum collection, the development of a single art project, which will both reveal the essence of the exhibition and fit the outline of art history. The attractiveness of a museum curator's exposition is important, but it does not play a core role.

The institution gives the curator stability and corporate protection, but at the same time limits his independence and burdens him with obligations and routine. Another of the museum curator's advantages, which at the same time turns into a disadvantage, is the access to the power and material resources of the institution (the authority of the museum, museum collection and site) which both fulfills and limits him ${ }^{20}$. The work of a museum curator can be called "invisible", which refers to the traditional concept of the museum as a rational, neutral and authoritative place where absolute truths and values prevail ${ }^{21}$. It is worth noting that this concept is more in line with how traditional art museums preserve classical art, while contemporary art museums often deviate from it.

The opposite of a museum curator is an independent curator. These are freelance curators who to some extent can choose for themselves the functions they would like to perform. Some of them can work with commercial galleries, being in charge of preparing exhibitions of resident artists, others organize mobile and stationary exhibitions as invited specialists in different institutions i. e. museums, still others work on international festivals and biennials and create their own pieces of curatorial art ${ }^{22}$.

However, the main difference between an institutional and an independent curator is that he is not permanently associated with an institution and does not obey its rules. We can say that he works as a "free artist", independently choosing which contemporary

\footnotetext{
${ }^{14}$ Miziano, 2014. P. 32-38; George, 2017. P. 14-16; Kartseva, 2019. P. 101.

15 George, 2017. P. 14-16.

16 Kartseva, 2019. P. 101.

17 George, 2017. P. 14.

18 Sapanzha, 2019. P. 155.

19 Miziano, 2014. P.32-33.

20 Ibid. P. 27-28.

21 O’Neill, 2015. P. 56.

22 George, 2017. P. 15.
} 
artists to work with, which institutions to collaborate with, and which ideas he would like to put forward.

Unlike the institutional curator, the independent curator is much more operational. The independent curator's specialization in certain artistic material is way less pronounced than that of a museum curator and is primarily shaped by the experience of collaborating with specific artists. The change of specialization of such a curator occurs constantly and proceeds easily and naturally ${ }^{23}$. In addition, an independent curator is not bound by the routine and obligations of a particular institution, which, according to some researchers, is much more consistent with the humane, subjective nature of curatorial practices. The curator puts not so much his professional knowledge and competence into the project as "all of himself" 24 , which fits much more the model of independent curator's activity. However, the position of this type of curator has also drawbacks: being outside the institution, they are doomed to a constantly uncertain future, and lack the necessary resources and platforms for the implementation of their projects ${ }^{25}$.

These two seemingly irreconcilable forms of curatorial practice - independent and museum curating - exist in a constant dialogue. Upon closer examination, this fact does not seem surprising: after all, one of the curators just happens to have what the other lacks. An independent curator needs resources and a platform to carry out his projects, while a museum curator needs fresh information and ideas, which are not provided by the routine of institutional life ${ }^{26}$.

But the curators' division into independent and institutional types does not cover all the complexity of curating. In view of this, researchers suggest other types of classifications which would make the functions of the curator clearer.

An interesting classification is implemented by Prilashkevich E. E. ${ }^{27}$, who distinguishes 4 types of curators which help us to understand the main functions of curators:

1) The curator-mediator is the one who is focused on mediation of the art project idea to the audience.

2) The curator-producer is the one who actualizes and introduces into the art market not an artistic work or project, but a special symbolic product with its own commercial success.

3) The curator-exhibitioner is the one who is in charge of creating and realizing the best possible way to represent certain material to the public is in close dialogue with all the stakeholders.

4) The curator-creator is the one who acts in conjunction with the artist as an active creative unit and creates its own piece of curatorial art.

Even though the functions of a curator can be widely defined, there is still the possibility to distinguish the three key directions of any curatorial practice. According to Prilashkevich, these practices are:

1) evaluation (consisting in primary and secondary qualitative valorization of the work of individual artists);

\footnotetext{
23 Miziano, 2014. P. 33-34.

24 Ibid. P. 32-33.

25 Ibid. P. 27-28.

26 Ibid. P. 28.

27 Prilashkevich, 2009. P. 16.
} 
2) designing (consisting in the development of the conceptual structure of the art project and the context of its understanding corresponding to the chosen problem);

3) performing (involving the practical implementation of an artistic project by following the methods of an appropriate strategy).

In this regard, one of the main strategies for implementing the curatorial idea is traditional curatorial research that consists in the curator's direct exploration of underdeveloped peripheral regions and finding new names ${ }^{28}$.

The complexity of the curatorship activity becomes easier to understand when looking at the concrete practices of curators in different institutions. In order to do so, let us turn to an examination of the activities of curators in various institutions where they usually work.

In the art gallery the curator is forced to focus on the economic component of the exhibits which is not less important than their conceptual and aesthetic aspects. His task is to balance the economic and artistic aspects of the project without reducing the quality of the exhibited works. Another task is to promote the discovery of new names that could later become particularly important for art. The curator evaluates the artworks considering both its quality and intended commercial successfulness.

Thus, the curator's activity in the gallery is aimed at the present and his main task is to select the best - qualitatively speaking, and economically sound works. The gallery curator needs to establish the artist on the market and make him recognizable, so an art project requires an interesting and memorable exhibition while the project's conceptual structure may remain rather narrow.

The work of the curator of festivals and biennials is the most striking embodiment of curatorial practice: within the framework of international exhibitions the curator is responsible for representing the most complete cross-section of contemporary art using international artistic material and displaying the most pressing problems of our time. Here curatorial competences should be particularly deep, and his original approach to organizing an exhibition should be determined by a wide range of parameters, including, for example, the geographical and cultural features of the event venue. The curator is evaluating the artists according to the analysis of contemporary art on the global scale: the creators' works must reflect the artistic trends in phase with the problems of the modern world.

The curator of the biennial is looking to the future, which gives him some kind of "visionary" task to establish the direction of further development in art and in society. His project is supposed to reflect in a clear and intelligible fashion the problems of the modern world while combining heterogeneous artistic phenomena from all over the world ${ }^{29}$.

The relations between curators and museums as an institution were already partly discussed above. The museum curator is working on collections and their representation in museums of different scales and profiles. And as long as the collections of most art museums consist of art of previous epochs, the curator has to constantly work with the past. Every phenomenon that he notes must have a solid foundation, prove its validity and the need to be reflected in the history of $\operatorname{art}^{30}$.

\footnotetext{
28 Ibid. P. 17-21.

${ }^{29}$ Ibid. P. 23-24.

${ }^{30}$ Ibid. P. 22.
} 
But museums nowadays also understand that they are forced to meet modern needs, so they strive to overcome self-absorption and become multi-disciplinary research, educational and partly entertainment centers focused on the present and even the future as much as on the past ${ }^{31}$. In that respect, museums look for the help of independent curators in order to achieve various goals.

Firstly, with the help of curators, museums are trying to invent new meaningful forms of interaction with the audience and expand it by using the tools of this institution only as a starting point ${ }^{32}$. If earlier the quality of museums' exhibitions was determined by their compliance with traditional scientific approaches, now the value orientation has shifted towards the originality of the interpretation of the museum collection. In this sense museums need curators as professionals who are able to suggest and realize the new "optics" of vision, the new idea of showing museum collections ${ }^{33}$.

Secondly, some museums organize special projects based on contemporary art in order to be closer to modernity. In organizing them, independent curators are also helpful for museums, and according to Biriukova M. V., the interactions between museums and such kinds of curatorial projects can take the following forms:

1) a curatorial project in the contemporary art museum, which is natural and necessary for this institution;

2) a curatorial project on the museum's platform for presenting contemporary art;

3) a curatorial project in the museum of classical art where inclusion of author's curatorial practices in the museum, demythologization and deconstruction of art is always perceived as extremely painful (for instance, the recent exhibition of Jan Fabre the State Hermitage Museum) ${ }^{34}$.

\section{Current issues of curatorship}

The intricacies to apprehend in a proper manner the profession of curator reflect the diversity of definitions at our disposal. These issues are not restricted to academic research but are the reality on the ground of everyday professionals who have to face the challenges of an ever evolving profession. To study and reflect on these challenges is the goal of the paper's authors, so now we'll speak about the problems of current curatorship we found the most interesting and essential to discuss.

One of the problems of curatorship today is partly reflected in the general dichotomy between independent and institutional curator we stated above. The problem we are speaking about basically deals with the attempts to converge the independent and institutional curators' functions.

As we already mentioned the role which a traditional museum curator is playing in organizing permanent and temporary exhibitions deeply varies from the one that independent curator plays. If independent curator's expositions are supposed to be original and modern in their theme and the chosen ways of representation, the museum curator in classical art museums is oriented to organizing exhibitions which include the minimum of

\footnotetext{
31 Karpova, 2014. P. 334.

32 Antonova et al., 2017. P. 25.

33 Safronov, 2019. P. 80.

34 Sapanzha, 2019. P. 155.
} 
his author's interpretation and maximum of correspondence to the scientific understanding of art material.

But as long as museums nowadays aspire to suit the modern age of society and art, they are looking for other ways of representing their collections than the neutral purely scientific ones. To achieve this goal, museums are not only inviting independent curators to make an exposition based on their material or just taking place on museum sites, but they are also training their own professionals to create more "independent" exhibitions, at least the ones of contemporary $\operatorname{art}^{35}$.

And that's where museums face complications. On the one hand, museum curators face the inner critique of the institution that asks for more original, problematized exhibitions from its own professionals ${ }^{36}$. But on the other hand, museums as institutions see independent curatorship as mostly a commercial activity that is producing and interpreting new fashioned art movements. Museums consider it as too close to art market and while understanding museums' scientific and non-commercial specificity do not want to be associated with independent curatorship ${ }^{37}$.

The problem is that the non-institutional status of independent curators and the originality as well as the experimentative character of their exhibitions are directly linked. Being outside of the institution, curators feel free to express any ideas and concepts that could possibly go against its authority. Moreover, some researchers state that truly curatorial projects always consist of questioning the very ways and techniques of art representation, self-reflective, deconstructive approach to the core of their own practice. The originality of curatorial pieces is seen as the direct consequence of curators' endless doubt in their activity which allows them to create a kind of new world of exhibition with its proper laws of space and time, rules of representation, etc. ${ }^{38}$

In this sense, the willingness of museums to reach the same level of exhibitions' originality as the one of independent curatorial projects might fail. The museum as an institution of stability and scientific authority which functions are based on the rules of objects' representation cannot be as self-reflective as independent curators' practice and call its own rules in question. Independent curatorship and traditional museum curatorship seem not to be able to exist within the same institutional system because of their fundamentally antagonistic nature. The only possible way for museums to organize more original and modern exhibitions might be to change their thematic content in order to make it more problematized, close to current issues and giving new interpretation to the collections. But to systematically doubt the very techniques and possibility of art representation will mean for traditional classic art museums to tear up the foundations of their own activity. That's why the levels of originality of independent and museum curators' exhibitions might always be qualitatively different.

One more crucial problem of curatorship nowadays is the underdevelopment of ethical rules about this new, but already established profession. Some curators think that curatorship is actually the ethics itself, as long as it deals with "taking care" according to the

${ }^{35}$ Kartseva, 2019. P. 103.

36 Oganes'iants, 2012. P. 608.

37 Ibid.

${ }^{38}$ Lecture by Victor Miziano "Curator: Attempt to Define" at the Jewish Museum and Tolerance Center, Moscow. Available at: https://www.youtube.com/watch?time_continue=694\&v=fAITiGhRNZA\&f eature=emb_logo (accessed: 29.07.2020). (In Russian) 
etymology of the term. But in spite of this, some ethical issues still appear in curatorial practices, and one of the reasons for this can be seen maybe in the fact that independent curators have no rules and corporate ethics to follow. Either ways, the ethical problems of curatorship are nowadays one of the most urgent and vividly discussed, and appear mostly in the interaction of curators with three main participants in the process of exhibitions' organization: the art institutions, the public and the artists ${ }^{39}$.

Independent curators which are meant as the most striking embodiment of this profession interact with various institutions: museums of classic and contemporary art, art galleries, exhibition spaces, festivals and biennials. While cooperating with them ethical problems of different kinds appear. For example, to which extent can a curator's exhibition be divergent from the policy and the specificity of the institution he works in? Should he respect the rules of the institution or has the curator the right to make his exposition as original as he wants? These questions remain open. Another question remains open when related to the side a curator should take in the case of a scandal or any other troublesome events related to the exhibition. It seems as if the curator and the institution should both take the responsibility for the product of their collaborative work, but sometimes it is in the curator's interest to stay away from the scandal, which might seem as an unethical practice ${ }^{40}$.

Some ethical issues can also appear regarding the curator's interaction with the public caused by the fact that any curator, on the one hand, wants to be understood by the public, and on the other - make original exhibitions that sometimes are difficult to understand. Does a curator have the right to organize projects with traumatic, unpleasant content or should he take into account the reception of the public to the detriment of his own ideas? Scandalous exhibitions can, to some degree, compromise the reputation of modern art in the public's eyes. But at the same time the experimentative character and author's originality are the core elements of curatorial practice, and to take them away will mean to ruin the base of curatorship ${ }^{41}$.

But the biggest, most visible and urgent ethical problem appears in the interaction between the curator and the artist. As long as today's curator is supposed to be the one who creates the pieces of art (curatorial and expositional) too, there comes an issue about how to organize unavoidable collaboration between him and the artist during the exhibition making process in order for the both of them to fully realize their artistic potentials.

The first well-known precedent when the problem of that kind appeared took place in Kassel in 1972. Harald Szeemann, at that time curator of "documenta V: Questioning Reality - Image World Today", created the genre of mega-exhibition where a curator plays the major role and has the right or even the duty to make his own epic statement based on artists' pieces. But some people, including the artist-participant of the exhibition Daniel Buren, saw in this new system of exposition and artistic relations the willingness of curators to become meta-authors. According to Buren, the curator within the megaexhibitions tends to subjugate the sovereignty of the artist and becomes a super-artist ${ }^{42}$.

With time mega-exhibitions in the form of biennials and festivals became the permanent part of the art sphere in general and curators' activity in particular. In organizing such events the decision making process is naturally taken over by curators, and in the end

\footnotetext{
39 Miziano, 2014. P. 216-217.

40 Ibid. P. 218-219.

41 Ibid. P. 222.

42 Ibid. P. 181.
} 
art producing is also to a large extent shifted into the hands of curators. It seems to be that curators might become more important with the increase in the number of artists exposed which would lead to frictions between artists and curators. Among the many instances of criticism from artists towards curators, the MoMA exhibition of 1968 "The Machine as Seen at the End of the Mechanical Age" comes to mind. The choice to select a particular artistic work, Télé-Sculpture, from Takis by the museum curator Pontus Hultén led to a controversy that culminated with the creation of the Art Worker's Coalition (AWC) in 1969.

Curators today recognize this ethical problem and try to find an appropriate solution to it. A good example of this reality are the exhibitions of Hans Ulrich Obrist, who usually avoids the big curatorial projects in favor of medium and small scale ones. An exception to this rule was the $9^{\text {th }}$ biennial of Lyon in 2007 co-curated by Hans Ulrich Obrist wanted the artists to be at the center of attention by themselves having the choice of the artists exposed. This "game" had the goal to render the role of the curator inoperative leaving the artists free of supposed coercive constraints. Nevertheless, what might seem as an opportunity for more democratic or horizontal relations between artists and curators has been also criticized by some. This biennial might have revealed the inherent flaws that a curator might never overcome, the simple fact that the curator is able to put himself in an observing position withdrawn from the reality of an exhibition comes from the very fact that he has set the rules to be in such a position. The very possibility for the curator to play a secondary role comes from the first role he always plays. The alternative exhibitions that Obrist or else wish to portray are stumbling on the institutional power structure which should always be taken into consideration ${ }^{43}$.

The question over how and who should find the solution to all these ethical problems remains debatable. Miziano believes that only the curator is the one who can solve these ethical issues as long as he is the figure which unites all the sides of the expositional work and is responsible for the eventual result. He also states that the accommodation which will really suit all the sides is ethically impossible, but possible practically - that is basically what the stakeholders find while organizing every single exhibition ${ }^{44}$.

The world of curatorship has not been spared by the evolution of the work market neither. The strict hierarchy and uncompromising institutional norms are falling at a rapid pace and the work environment of the curator is on the path to greater flexibility and precariousness. These evolutions can be explained by established institutions' willingness to "catch up" with the most contemporary trends in the art industry leading to a higher degree of freedom given to curators. But as goes the saying - "With great power comes great responsibility", thus allowing for ethical questions to be at the forefront of curatorial practices and academic research.

This trend can be observed having the opposite effect on the ethical questioning previously studied: the liberalization of the work environment in the workplace in general and in the art industry as well started at the end of the $20^{\text {th }}$ century leading to the injunction as well as the incentive for employees (and certainly curators are among them) to view themselves as entrepreneurs of their own life ${ }^{45}$. Being an entrepreneur of oneself is certainly an obligation in a work environment that is characterized by the flexibility of the profession, the seemingly confusion between a freelance curator and an institutional one

${ }^{43}$ Rogoff, 1998. P. 142.

${ }^{44}$ Miziano, 2014. P. 222-223.

${ }^{45}$ Foucault, 2004. 
as well as the precariousness of a majority of those entering the job market with curatorial ambitions. Needless to say that the deconstruction of the stringent rules of the art institutions have allowed the stable, certain and persistent relations among stakeholders to vanish in favour of more transactional relations in networks where each tries to permanently grow his own. In this environment it is not surprising that some foresaw already in the 1990s the end of the function of critique ${ }^{46}$ because of the transformations of the art world which focuses more on the positive image than a critical approach no stakeholders really needs. Following Byung-Chul $\mathrm{Han}^{47}$ it is safe to assume that the profession of curator is overwhelmed by the overflow of positivity that risks rendering even the possibility of self-criticism let alone an ethical reflection about one's own profession superfluous if not useless.

\section{Conclusion}

The history of curatorship is one that is diverse and eventful. From the establishment of cabinets of curiosities to the organization of internationally renowned biennials, the profession of curator has made a lot of progress. The evolutions of the art industry has been detrimental for the type of practices curators had to accomplish through the centuries, from simply being art "selectors" to co-artists in most recent events to becoming full-fledged artists themselves. These changes do not affect all curators, of course, but do influence the distribution of responsibilities for those curators having multiple loyalties and duties inside of the institutions.

The paper tried to make sense of the ambivalent work of curating today by going through the sometimes irredeemable complexities of curatorship. This complexity is exemplified in the work of Prilashkevich E. E. ${ }^{48}$ through her multilayered ideal-typical account of curatorship. Moreover, its problematic nature can also be seen in various challenges facing curatorship nowadays, challenges which the authors explored in the article, such as ethical issues, the convergence of functions between independent and institutional curators and even the influence of the work conditions. As an art lover a curator seems to be well aware of the issues his profession entails, but it is the practical feasibility to act accordingly which is put into perspective here. We also discovered that the curator faces the constraints of the institutions he is working in as well as sometimes the self-aggrandizing nature of its ego resulting in its prominent role. Lastly, the paper touched upon a phenomenon that affects independent curators and institutional ones alike which is the flexibilization and the precariousness shaping curating and its ability to reflect on its own profession. And it is this very latter aspect which is concerning because self-criticism seems to represent such an important part of the latest developments of curatorship.

\section{References}

Antonova E. L., Luk'ianova A. A., Turkina V. G. 2017. Art curatorship as a phenomenon of contemporary museum activity. Prague: Vědecko vydavatelské centrum "Sociosféra-CZ". (In Russian)

Byung-Chul H. 2015. The Transparency Society. Palo Alto: Stanford University Press.

\footnotetext{
46 Žerovc, 2005. P. 138-153.

47 Byung-Chul, 2015.

48 Prilashkevich, 2009.
} 
Foucault M. 2004. Naissance de la biopolitique, Cours au Collège de France (1978-1979). Paris: Seuil.

George A. 2017. The Curator's Handbook: Museums. Commercial Galleries. Independent Spaces. Rus. Ed. Moscow: Ad Marginem Press. (In Russian)

Glicenstein J. 2015. L'invention du curateur. Mutations dans l'art contemporain. Paris: Presses Universitaires de France.

Karpova P. S. 2014. Analysis of the problems of curating art projects in the system of contemporary art. Problemy sovremennogo gumanitarnogo obrazovaniia glazami molodezhi. Sbornik materialov konferentsii (Moscow, 2-4 dec. 2015). Moscow: 333-336. (In Russian)

Kartseva E. A. 2019. Exhibition and gallery practices: a tutorial. Moscow: Directmedia Publ. (In Russian)

Marincola P. (ed.). 2001. Curating Now. Imaginative Practice/Public Response. Philadelphia: Philadelphia Exhibitions Initiative.

Miziano V. 2014. Five lectures on curating. Moscow: Ad Marginem Press. (In Russian)

O'Neill P. 2015. The Culture of Curating and the Curating of Culture(s). Rus. Ed. Moscow: Ad Marginem Press. (In Russian)

Obrist H. U. 2016. Ways of Curating. Rus. Ed. Moscow: Ad Marginem Press. (In Russian).

Oganes'iants M.S. 2012. Museum curatorship as a factor in the actualization of contemporary art: on the example of the activities of the Department of Contemporary Art of the Russian Museum. Iskusstvoznanie 3-4: 599-610. (In Russian)

Prilashkevich E. E. 2009. Curating in contemporary artistic practice. Diss. abstract. St. Petersburg. Available at: https://dlib.rsl.ru/viewer/01003475013 ?page=1 (accessed: 30.07.2020). (In Russian)

Rogoff I. 1998. How to dress for an exhibition. Stopping the Process? Contemporary views on Art and Exhibitions. Nordic Institute for Contemporary Art. Helsinki: 130-149.

Safronov N.S. 2019. Curatorship as a cultural phenomenon of the $20^{\text {th }}-$ early $21^{\text {st }}$ century. Vestnik kul'tury i iskusstv 1 (57): 73-83. (In Russian)

Sapanzha O.S. 2019. [Book rev.:] Biriukova M. V. Philosophy of curating. St. Petersburg: Dmitrii Bulanin, 2018. Muzei. Pamiatnik. Nasledie 1 (5): 152-157. (In Russian).

Žerovc B. 2005. The role of the contemporary art curator. A historical and critical analysis. MJ-Manifesta Journal. Journal of Contemporary Curatorship 5: 138-153.

Received: August 5, 2020

Accepted: September 28, 2020

Authors' information:

Elizaveta V.Rubantseva - Bachelor Student; e_rubantseva@mail.ru

Loup Hoffmann - Master Student; louphoffmann@gmail.com

\section{Куратор в сфере искусства и в музее: история, теории и актуальные проблемы}

\section{Е. В. Рубанцева}

${ }^{1}$ Санкт-Петербургский государственный университет, Российская Федерация, 199034, Санкт-Петербург, Университетская наб., 7-9

2 Университет Сорбонны, Франция, 75006, Париж, ул. Медицинской школы, 21

Для цитирования: Rubantseva E. V., Hoffmann L. 2020. The curator in the art world and in the museum: History, theories and current issues. Вопросы музеологии, 11 (2), 168-182.

https://doi.org/10.21638/11701/spbu27.2020.203

В статье анализируется современное состояние кураторства как профессионального института и вида деятельности с исторической, теоретической и практической точки зрения. Основная цель работы - понять причины и суть обоснованной критики данного института, исходящей сегодня как от самих кураторов, так и от художников, представителей арт-институций и арт-критиков, а также исследовать трудности, с которыми он сталкивается. Для достижения этой цели в начале статьи авторы прослеживают историю кураторства - сравнительно молодой и продолжающей активно раз- 
виваться профессии. Окончательно возникнув в его современном понимании в 1960 1970-е гг. XX в., кураторство художественных выставок на протяжении всего своего становления постепенно отделялось от смежных сфер деятельности, а кураторы шаг за шагом выстраивали отношения с другими участниками выставочного процесса художниками, арт-институциями и публикой. Находясь на переплетении всех нитей организации выставки и являясь в то же время медиатором между художником и публикой, куратор занимает сложное положение в системе искусства. Отражением противоречивости и многоаспектности этой деятельности являются рассмотренные во второй части статьи теоретические изыскания как ученых, так и самих кураторов-профессионалов, позволяющие оценить все многообразие функций, типов, определений кураторов и кураторских практик. Наконец, основываясь на историческом и теоретическом анализе кураторства, предпринятом ранее, авторы исследуют современное положение куратора в арт-сфере, а также проблемы и критику, с которыми сталкивается сегодня этот институт. Среди них наиболее пристальное внимание в статье было уделено сложным этическим проблемам, возникающим при взаимодействии кураторов с художниками, институциями и публикой, а также тревожному сближению функций независимого и музейного куратора и отчасти негативному влиянию условий труда на методы работы этих профессионалов. В конечном итоге авторы приходят к выводу, что указанные выше остро стоящие проблемы являются действительно важными для современного кураторства. Однако представляется, что далеко не все эти проблемы возможно полностью разрешить, так как их природа связана с многолетним и неизбежным конфликтом интересов между участниками выставочного процесса.

Ключевые слова: кураторство, выставка, куратор, независимый куратор, музейный куратор, типы кураторов, история кураторства, музей, биеннале, художник.

Статья поступила в редакцию 5 августа 2020 г.; рекомендована к печати 28 сентября 2020 г.

Контактная информация:

Рубаниева Елизавета Витальевна - студент бакалавриата; e_rubantseva@mail.ru Лю Хофбманн - студент магистратуры; louphoffmann@gmail.com 